\title{
Pengaruh Penerapan Media Interaktif Berbasis Multimedia Untuk Pembelajaran Bahasa Inggris Di MTs. NW Ketangga Menggunakan Algoritma Naïve Bayes
}

\author{
Yahya1, Amri Muliawan Nur2 \\ 1,2Program Studi Sistem Informasi, Universitas Hamzanwadi \\ ayhay7078@gmail.com
}

\begin{abstract}
Abstrak
Era digital adalah sebuah era dimana hampir semua kegiatan sehari-hari dipermudah dengan adanya teknologi. Masuknya kita dalam era digital menjadi salah satu pertanda bahwa akan ditinggalkannya cara-cara lama yang kemudian digantikan dengan teknologi dan cara-cara baru yang lebih praktis dan modern. Perubahan-perubahan tersebut telah mengubah cara pandang serta praktik-praktik pembelajaran dalam dunia pendidikan saat ini. Dalam rangka menjalankan pendidikan yang efektif dan efisien, adanya media pembelajaran merupakan hal yang sangat mendesak, terutama di masa yang akan datang. Terlebih lagi semenjak virus COVID-19 melumpuhkan hampir semua aktivitas dan memberikan pengaruh yang sangat besar dalam aktivitas belajar-mengajar di sekolah. Penggunaan media pembelajaran berbasis multimedia pada pelajaran bahasa Inggris diharapkan dapat meningkatkan antusias dan interaksi yang terjalin antara guru dan siswa. Mengingat bahwa bahasa Inggris telah menjelma menjadi bahasa yang paling sering digunakan diberbagai negara, baik dalam kehidupan bersosial ataupun saat berada di lingkungan kerja. Media pembelajaran akan dilengkapi oleh animasi yang akan menarik perhatian peserta didik, serta dengan penjelasan yang akan membuat peserta didik lebih cepat memahami pelajaran. Selain itu terdapat unsur tambahan lainnya berupa audio, untuk mempermudah siswa dalam memahami pronunciation atau pengucapan kata atau kalimat yang ada di materi pelajaran. Penerapan media interaktif ini akan digunakan sebagai baha untuk memperoleh data tentang pengaruh media interaktif dalam peningkatan pemahaman belajar siswa. Hasil pendataan diolah menggunakan Tools RapidMiner 5.0 dan Algoritma Naïve Bayes. Hasil pengolahan data menunjukkan nilai akurasi sebesar $90.96 \%$, yang berarti bahwa penerapan media interaktif pada mata pelajaran Bahasa Inggris di MTs. NW Ketangga sangat berpengaruh dalam meningkatkan minat dan kemampuan siswa dalam memahami materi yang disampaikan.
\end{abstract}

Kata kunci: Media pembelajaran, Naïve Bayes, Bahasa Inggris.

\begin{abstract}
The digital era is an era where almost all daily activities are facilitated by the presence of technology. Our entry into the digital era is a sign that old ways will be abandoned which are then replaced with new technologies and ways that are more practical and modern. These changes have changed the perspective and practice of learning in the world of education today. In order to carry out an effective and efficient education, the existence of learning media is very urgent, especially in the future. Moreover, since the COVID-19 virus has paralyzed almost all activities and has had a very large influence on teaching and learning activities at schools. The use of multimedia-based learning media in English lessons is expected to increase enthusiasm and interaction between teachers and students. Given that English has become the language most often used in various countries, both in social life and in the work
\end{abstract}


environment. Learning media will be equipped with animations that will attract the attention of students, as well as with explanations that will make students understand the lesson faster. In addition, there are other additional elements in the form of audio, to make it easier for students to understand the pronunciation or pronunciation of words or sentences in the subject matter. The application of this interactive media will be used as material to obtain data about the effect of interactive media in increasing student understanding. The data collection results were processed using RapidMiner 5.0 Tools and the Naïve Bayes Algorithm. The results of data processing show an accuracy value of $90.96 \%$, which means that the application of interactive media to English subjects in MTs. NW Ketangga is very influential in increasing students' interest and ability in understanding the material presented.

Keywords: Learning media, Naïve Bayes, English

\section{Pendahuluan}

Era digital adalah sebuah era dimana hampir semua kegiatan sehari-hari dipermudah dengan adanya teknologi. Masuknya kita dalam era digital menjadi salah satu pertanda bahwa akan ditinggalkannya teknologi atau cara-cara lama yang kemudian digantikan dengan teknologi dan cara-cara baru yang lebih praktis dan modern. Era digital memberikan peluang bagi mereka yang siap akan perubahan, dan bagi mereka yang tidak menghendaki adanya perubahan tentu saja akan sulit untuk menyesuaikan diri. Perubahanperubahan tersebut telah mengubah cara pandang serta praktik-praktik pembelajaran dalam dunia pendidikan saat ini.

Bahasa Inggris adalah bahasa resmi negara Inggris, namun dengan berkembangnya teknologi, bahasa Inggris kini semakin dikenal dan dipelajari oleh banyak orang. Selain itu, menurut Rahayu bahasa Inggris dijuluki sebagai Lingua Franca global karena merupakan bahasa yang dominan digunakan di sebagian besar negara [1]. Maka tak heran jika bahasa Inggris telah menjelma menjadi bahasa yang paling sering digunakan di berbagai negara, baik dalam kehidupan bersosial ataupun saat berada di lingkungan kerja. Kegiatan pembelajaran bahasa Inggris di sekolah secara umum hanya menggunakan media buku namun belum maksimal [2]. Menurut Ekayani media pembelajaran merupakan segala sesuatu yang digunakan untuk merangsang pikiran, perasaan, perhatian, dan kemampuan siswa untuk mendorong terjadinya proses belajar. Proses pembelajaran merupakan proses komunikasi yang terjadi dalam satu sistem, sehingga media pembelajaran menempati posisi yang cukup penting sebagai salah satu komponen sistem pembelajaran [3]. Penggunaan media pembelajaran interaktif khususnya dalam pembelajaran bahasa dapat memberikan dampak positif dalam menambah hafalan kosakata. Selain itu, media pembelajaran interaktif juga memberikan visual dan interaktivitas dengan 
siswa sehingga lebih aktif dalam belajar dan hasil belajar menjadi lebih meningkat.

MTs. NW Ketangga bertempat di Jalan Hasanuddin Kembang Sari, Kecamatan Selong Lombok Timur, berdiri di bawah naungan Yayasan Pendidikan Nahdlatul Wathan Cabang Selong. Berdasarkan hasil wawancara yang dilakukan oleh penulis dengan guru mata pelajaran bahasa Inggris, bahwa metode pengajaran yang diterapkan masih menggunakan cara lama. Dimana guru menjelaskan materi berdasarkan modul pegangan menggunakan papan tulis. Sehingga tak jarang siswa mengalami rasa jenuh, khususnya siswa kelas VII. Siswa kelas VII masih mengalami kendala dalam mempelajari bahasa Inggris, dikarenakan karakter siswa yang lebih tertarik pada hal-hal seperti animasi yang dikombinasikan dengan berbagai macam bentuk dan warna, suara, dan lain-lain. Karena masih menggunakan metode lama, sehingga seringkali materi disampaikan secara berulang. Selain itu biasanya guru memilih materi pelajaran yang akan disampaikan secara random, didasarkan pada kemampuan dan kesiapan para siswa. Untuk materi yang dirasa lebih mudah akan didahulukan, adapun bagi materi-materi yang dirasa lebih rumit akan ditunda penyampaiannya.

Berdasarkan pemaparan permasalahan di atas, maka dari itu peneliti tertarik untuk membuat media pembelajaran interaktif berbasis multimedia pada materi "Unit 7: The Cat is Cute" untuk siswa kelas VII di MTs. NW Ketangga yang sesuai sehingga dapat mempermudah siswa dalam menerima materi, meningkatkan motivasi dan antusias para siswa dalam belajar. Selain itu, pembuatan media pembelajaran juga akan memberikan kemudahan bagi guru dalam menjalankan kegiatan belajar mengajar.

\section{Tinjauan Pustaka}

\subsection{Penelitian Terkait}

- Dari penelitian yang dilakukan oleh Fathurrahman et al[4] dalam jurnal berjudul "Media Pembelajaran Interaktif Pengenalan Huruf Berbasis Flash Pada Siswa Pendidikan Usia Dini (PAUD) (Studi Kasus: Kelompok Belajar Tarbiyatul Ummah Tanak Kaken Sakra Barat)" menjelaskan bahwa PAUD Tarbiyatul Ummah Tanak Kaken masih mengandalkan metode konvensional seperti buku, papan tulis, dan alat peraga dalam aktivitas belajar-mengajar. Media tersebut dirasa kurang menarik oleh siswa terutama dalam hal pengenalan huruf-huruf abjad. Pembuatan media pembelajaran dilakukan untuk dapat menarik minat belajar siswa, serta dapat mempermudah guru dalam proses belajar-mengajar. Dikarenakan media pembelajaran ini menggabungkan antara suara, gambar, dan video yang dikemas dengan menarik. 
Infotek : Jurnal Informatika dan Teknologi

Vol. 5 No. 1, Januari 2022

Hal. 209-218

e-ISSN 2614-8773

- Penelitian selanjutnya dilakukan oleh Sudianto \& Samsu[5] dengan judul "Media Pembelajaran Interaktif Pelajaran Bahasa Indonesia Berbasis Android Untuk Kelas VII Madrasah Tsanawiyah Nahdlatul Wathan Ketangga Sebagai Upaya Untuk Peningkatkan Minat Belajar Siswa" menjelaskan bahwa hasil pengamatan peneliti di MTs. NW Ketangga kelas VII, motivasi dalam belajar bahasa Indonesia sangat rendah. Siswa lebih banyak teralihkan untuk melakukan hal lain, seperti membuat onar, berbicara dengan temannya, dan tidur. Karena metode ceramah dan papan tulis yang digunakan oleh guru hanya membuat siswa menjadi pasif. Aplikasi media pembelajaran berbasis android yang dibuat oleh peneliti berisikan materi, kuis, video, dan chat yang membantu siswa dalam mengembangkan kompetensi dan tentunya menarik minat belajar siswa.

- Sedangkan pada penelitian yang dilakukan oleh Ayuningtyas[6] yang berjudul "Media Pembelajaran Mengenal Hewan Dalam Bahasa Inggris Berbasis Multimedia Interaktif" menjelaskan bahwa dalam proses belajar penggunaan alat peraga dapat sangat membantu siswa dalam memahami materi. Dalam upaya menarik perhatian siswa pada saat kegiatan belajar-mengajar berlangsung, maka guru perlu menggunakan metode yang dimana objek pelajaran disajikan untuk kemudian ditunjukkan kepada siswa. Karena menciptakan suasana belajar yang menyenangkan harus melibatkan semua panca indra. Hasil dari penelitian ini menunjukkan bahwa aplikasi multimedia interaktif pengenalan nama-nama hewan dapat memberikan visualisasi tentang nama-nama hewan melalui gambar dan animasi, sehingga suasana belajar lebih interaktif.

- Menurut "Yongheng Yang" dalam artikelnya yang berjudul "Hotspot diagnosis for solar photovoltaic modules using a Naive Bayes classifier" menyimpulkan bahwa "To achieve so, the texture and histogram of gradient (HOG) features of thermal images of PV modules are used for classification. The categorized hotspots are detected by training the machine learning algorithm, i.e., a Naive Bayes (nBayes) classifier. Experimentalresults are performed on a 42.24-kWp PV system, which demonstrates that a mean recognition rate of around $94.1 \%$ is achieved for the set of 375 samples[7]

- Menurut Yupi Kuspandi Putra adalam artikelnya yang berjudul "Perbandingan Algoritma Naive Bayes dan Naive Bayes Berbasis PSO untuk Analisis Kredit pada PT. BPR Syariah Paokmotong", setelah 
melakukan pengujian dengan model algoritma Naive Bayes sebesar $71.00 \%$, sedangkan dengan model Algoritma Naive Bayes berbasis Particle Swarm Optimization menghasilkan nilai akurasi yang lebih tinggi yaitu $88.51 \%$ dibandingkan dengan model algoritma Naive Bayes. Dari hasil tersebut didapatkan selisih antara kedua model yaitu $17.51 \%[8]$.

- Menurut Muhammad Wasil, Mahfuz dalam penelitiannya yang berjudul "Analisis Persepsi Masyarakat Terhadap Kinerja Aparatur Desa Dalam Meningkatkan Pelayanan Publik Di Desa Lenek Lauk Menggunakan Metode Naive Bayes" menghasilkan kesimpulan bahwa penelitian dilakukan dengan Metode algoritma naïve bayes, berfungsi untuk melihat tingkat akurasinya. Pengukuran dengan algoritma naïve bayes menghasilkan akurasi $92.26 \%$ dan nilai AUC pada Kurva ROC adalah sebanyak 0.924[9].

Dengan demikian, maka pembuatan dan penerapan media pembelajaran interaktif selayaknya harus dilakukan, guna meningkatkan kualitas pada kegiatan belajar-mengajar. Maka dari itu, pada penelitian ini penulis membuat media pembelajaran interaktif berbasis multimedia dengan tahapan seperti yang tertuang pada roadmap berikut ini:

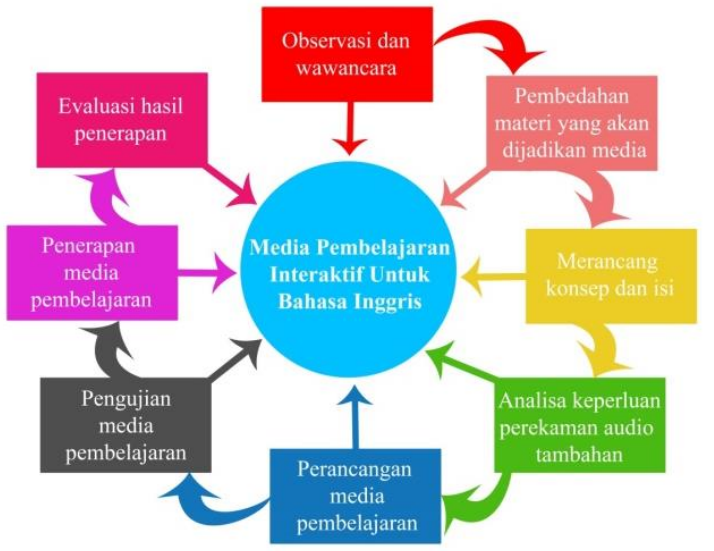

Gambar 2. 1 : Roadmap Penelitian

Untuk lebih jelasnya dalam setiap tahapan pelaksanaan, berikut ini merupakan alur penelitian yang dibuat dalam bentuk flowchart:

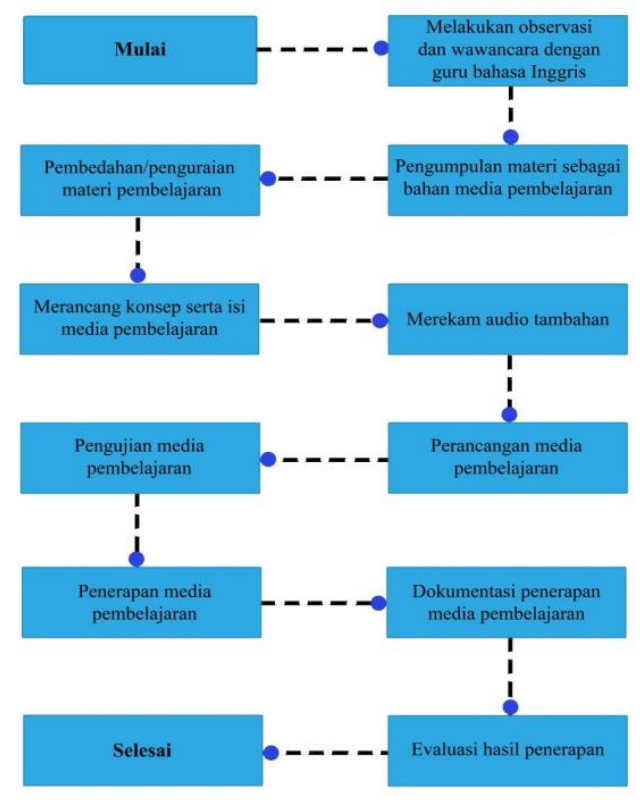

Gambar 2. 2 : Bagan Penelitian

\subsection{Landasan Teori}

1. Definisi Data

Menurut Chitrakant Banchhor, Dr. N. Srinivasu dalam artikelnya mengatakan bahwa data besar semakin banyak digunakan di berbagai bidang: seperti industri, transaksi keuangan, kedokteran, 
dan sebagainya, karena dapat menangani tantangan dalam memproses data dalam jumlah besar. Salah satu teknik penambangan data yang digunakan secara luas dan efektif untuk mengklasifikasikan data besar adalah model MapReduce[10]

Untuk membuat prediksi akurasi, perlu dilakukan pengelompokan sampel yang cukup yang dikumpulkan dari berbagai sumber. Privasi dan masalah keamanan informasi pribadi muncul dalam beberapa tahun terakhir, yaitu, pemilik data dapat dengan keras memungkinkan entitas yang tidak dipercaya untuk mendapatkan akses ke data sensitif mereka, yang membatasi sentralisasi trainer dari kumpulan data sampel[11].

\section{Algoritma Klasifikasi}

Masalah mengklasifikasikan data adalah topik populer dalam pembelajaran mesin dan statistik. Klasifikasi adalah untuk mengidentifikasi untuk kategori apa observasi baru tersebut didasarkan pada set data. Metode heuristik konvensional, seperti pengklasifikasi Naive Bayes telah banyak digunakan dalam banyak aplikasi[12]

\section{Naive Bayes}

Naive Bayes (NB) adalah salah satu dari 10 algoritma penambangan data teratas. Namun, asumsi independensi kondisional jarang berlaku dalam aplikasi dunia nyata. Untuk mengurangi asumsi ini, banyak pendekatan pembobotan atribut telah diusulkan. Namun, beberapa di antaranya secara simultan memperhatikan granularitas horizontal nilai atribut dan granularitas vertikal label kelas[13]

Naive Bayes Classifier adalah algoritma yang efisien dan efektif untuk pembelajaran mesin dan penambangan data. Berbasiskan Naive Bayes Classifier pada kombinasi Bayes Theorem dan atribut independensi anggapan. Naive Bayes Classifier didasarkan pada asumsi yang disederhanakan nilai-nilai atribut independen secara kondisional, dengan asumsi dari nilai target yang diberikan [14]

\section{Metode Penelitian}

\subsection{Tahapan Penelitian}

Tahapan penelitian mencakup langkah-langkah yang dilakukan peneliti dari awal hingga akhir penelitian. Adapun tahapan penelitian dituangkan dalam diagram alir di bawah ini:

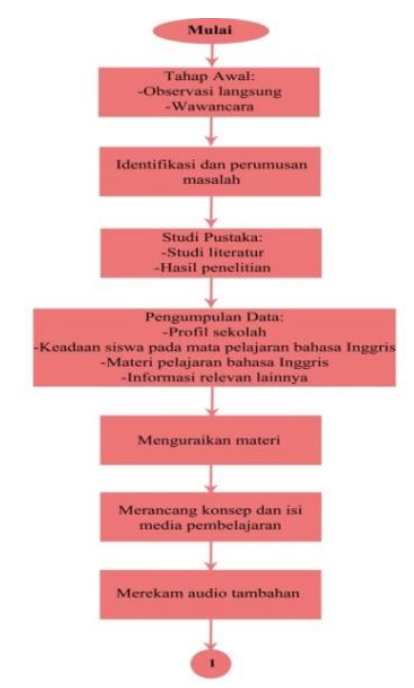

Gambar 3. 1 : Diagram Alir Tahapan Penelitian 


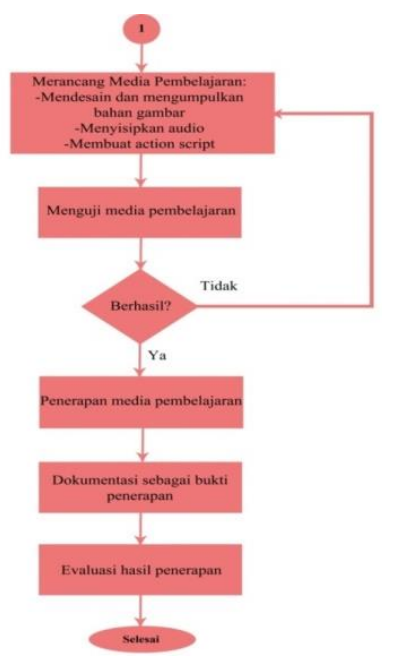

Gambar 3. 2 : Diagram Alir Tahapan Penelitian

$$
\text { (Lanjutan) }
$$

\subsection{Metode Penelitian}

Untuk memperoleh data dalam penelitian ini dilakukan dengan beberapa cara antara lain :

- Observasi

Observasi dilakukan dengan cara melakukan pengamatan terhadap beberapa kegiatan pembelajaran di MTs. NW Ketangga. Dari tindakan observasi ini diperoleh beberapa informasi tentang apa yang akan dilakukan, apa yang hendak diperoleh, bagaimana mendapatkan data serta cara mengolah data serta algoritma yang akan diterapkan yang sesuai dengan type data yang didapatkan.

- Interview

Interview atau wawancara dilakukan dengan mengambil beberapa responden sebagai bahan awal melakukan penelitian yang meliputi 2 unsur yaitu guru dan siswa didik.

- Angket
Angket atau quisioner dilakukan untuk memperoleh data tentang informasi pengaruh penerapan media interaktif terhadap proses belajar Bahasa Inggris pada MTs. NW Ketangga.

\section{Hasil dan Pembahasan}

Pada bab ini dilaporkan tentang hasil yang sudah dicapai dalam rangkaian kegiatan penelitian yang dilaksanakan dari bulan Januari 2021 s/d Agustus 2022.

\subsection{Penentuan Sumber Data}

Pada bagian ini, dicantumkan atau dilaporkan tentang hasil yang telah bisa dicapai dalam progres penelitian internal ini. Progres yang telah dicapai antara lain : 1. Pembuatan aplikasi media pembelajaran bahasa inggris. 2. Pengumpulan data responden quisioner untuk menggali informasi tentang manfaat media pembelajaran interaktif. Data responden diperoleh dari bagian tata usaha MTs. NW Ketangga sebanyal 155 orang, yang terdiri dari siswa, guru dan staf MTs. NW Ketangga, seperti yang digambarkan pada tabel berikut :

\subsection{Pengolahan Data}

Pengolahan data dilakukan dengan menggunakan algoritma Naive Bayes dengan melakukan 4 kali percobaan berdasarkan K-Fold Validation. Hasil pengolahan data ditunjukkan sebagai berikut : 
- $\quad$ Hasil Akurasi : K-Vold Validation 7

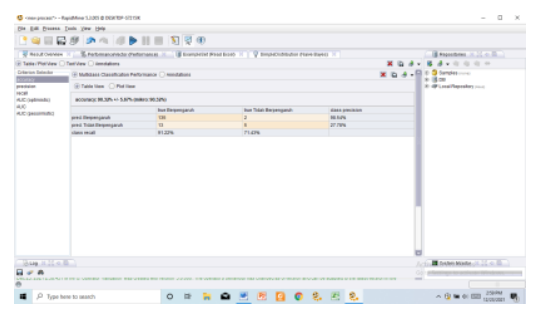

Gambar 4. 1. Nilai akurasi K-Fold Validation 7

- $\quad$ K-Vold Validation 8

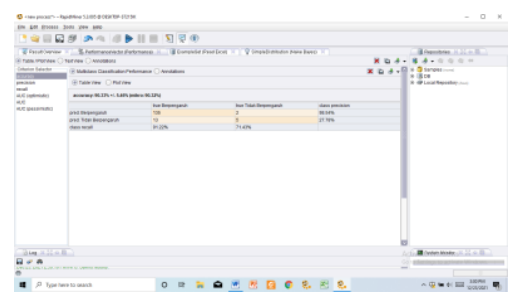

Gambar 4. 2. Nilai akurasi K-Fold Validation 8

- $\quad$ K-Vold Validation 9

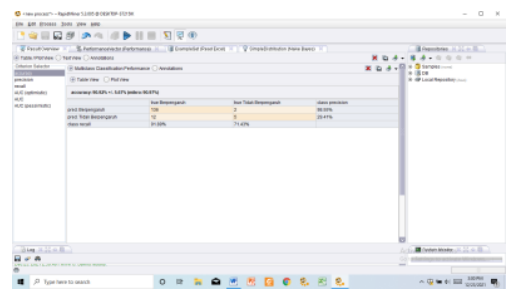

Gambar 4. 3. Ni Nilai akurasi K-Fold Validation 9

- K-Vold Validation 10

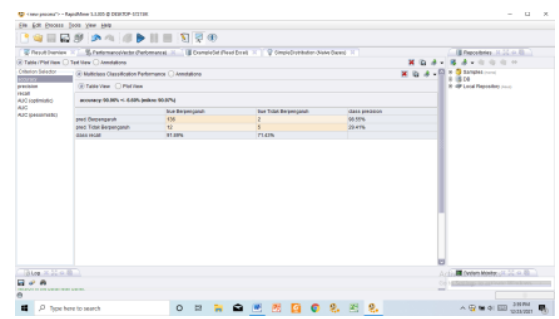

Gambar 4. 4. Nilai akurasi K-Fold Validation 10

4.3. Rekapitulasi hasil percobaan :

\begin{tabular}{|c|c|}
\hline K-Fold Validation & Akurasi \\
\hline K-F Validation 7 & $90,32 \%$ \\
\hline K-F Validation 8 & $90,33 \%$ \\
\hline K-F Validation 9 & $90,92 \%$ \\
\hline K-F Validation 10 & $90,96 \%$ \\
\hline
\end{tabular}

\section{Kesimpulan}

Simpulan dari penelitian ini adalah:

- Pembuatan media pembelajaran telah dibuat sesuai dengan perancangan antarmuka yang telah dirancang sebelumnya sehingga media pembelajaran sudah dapat digunakan dalam proses belajar mengajar.

- Pengujian dilakukan dengan menunjukkan respon yang baik, yaitu tidak adanya error dan semua bagian-bagian dalam media pembelajaran berfungsi dengan semestinya.

- Media pembelajaran interaktif dibuat dengan memasukkan kelima unsur multimedia yaitu animasi, suara, video, gambar, dan tulisan. Sehingga diharapkan dapat meningkatkan ketertarikan dan semangat siswa.

- Media pembelajaran interaktif dibuat berdasarkan empat aspek dalam bahasa Inggris, yaitu Listening, Speaking, Writing, dan Reading. Selain itu juga terdapat menu Evaluasi dan Vocabulary untuk menguji kemampuan siswa dan memperbanyak kosakata yang dapat membantu dalam mempelajari materi Descriptive Text.

- Percobaan dilakukan sebanyak 4 kali dengan menggunakan K-Fold Validation yang berbedabeda. Hasil yang diperoleh menggunakan KFold Validation yang berbeda-beda adalah nilai akurasi yang berbeda bahkan telah menunjukkan bahwa semakin besar K-Fold 
Validation, maka nilai akurasinya semakin besar.

- Nilai akurasi tertinggi diperoleh pada percobaan menggunakan K-Fold Validation 10 dengan nilai akurasi $90,96 \%$.

- Dengan data berdasarkan K-Fold Validation 10 dengan akurasi 90,96\%, menunjukkan bahwa penggunaan media pembelajaran interaktif pada mata pelajaran bahasa inggris di MTs. NW Ketangga, sangat berpengaruh dan perlu ditingkatkan penggunaan media interaktif untuk menarik minat para siswa untuk mengikuti dan merespon pembelajaran bahasa inggris.

- Jumlah responden yang menyatakan berpengaruh terhadap penerapan dan penggunaan Media Interaktif adalah 141 responden dari 155 responden yang dikumpulkan. Sehingga disimpulkan bahwa penerapan media interaktif sangat berpengaruh dalam menarik minat siswa untuk belajar.

\section{Daftar Pustaka}

[1] R. Sri Rahayu, "Studi Literatur: Peranan Bahasa Inggris Untuk Tujuan Bisnis Dan Pemasaran," vol. 1, no. 4, p. 149, 2018.

[2] A. R. Nursifa, A. Orinda, and S. S. Pritanti, "Media Pembelajaran Interaktif Bahasa Inggris Kelas V Sekolah Dasar Negeri 02 Cinere," J. CorelT J. Has. Penelit. IImu Komput. dan Teknol. Inf., vol. 3, no. 1, p. 9, 2018, doi: 10.24014/coreit.v3i1.3381.

[3] P. (2017) Ekayani, "Pentingnya Penggunaan Media," no. March, 2017, [Online]. Available: https://www.researchgate.net/publication/3 15105651.
[4] M. S. Fathurrahman Fathurrahman, Yupi Kuspandi Putra, "Media Pembelajaran Interaktif Pengenalan Huruf Berbasis Flash Pada Siswa Pendidikan Anak Usia Dini (PAUD)(Studi Kasus: Kelompok Belajar Tarbiyatul Ummah Tanak Kaken Sakra Barat)," Inform. dan Teknol., vol. 3, no. 2, pp. 211-219, 2020.

[5] L. M. S. Aris Sudianto, "Penerapan Media Pembelajaran Interaktif Pelajaran Bahasa Indonesia Berbasis Android Untuk Kelas Vii Madrasah Tsanawiyah Nahdlatul Wathan Ketangga Sebagai Upaya Untuk Peningkatkan Minat Belajar Siswa Aris," Infotek J. Inform. dan Teknol., vol. 2, no. 1, pp. 53-60, 2019.

[6] I. Ayuningtyas, M. A. Fadhilah, and R. W. Arifin, "Media Pembelajaran Mengenal Hewan Dalam Bahasa Inggris Berbasis Multimedia Interaktif," PIKSEL Penelit. IImu Komput. Sist. Embed. Log., vol. 6, no. 1, pp. 85-94, 2018, doi: 10.33558/piksel.v6i1.1403.

[7] B. Hariman, "Sistem Informasi Wisata dan Budaya Pulau Lombok dengan Multimedia Intraktif Untuk Meningkatkan Kunjungan Wisata," vol. 1, no. 1, pp. 1-10, 2018.

[8] B. H. Hariman Bahtiar, Muhamad Wasil, "Digitalisasi Karya TGKH. Muhammad Zainuddin Abdul Madjid berbasis mobile sebagai media pembelajaran interaktif untuk pelestarian peninggalan pendiri Nahdlatul Wathan," vol. 2, no. 1, pp. 1-7, 2019.

[9] R. Gita Ardhy Nugraha, "Pengembangan Media Interaktif Berbasis Adobe Flash CS4 Professional Pada Pembelajaran Tematik Untuk Siswakelas 2 SD," J. Chem. Inf. Model., vol. 7, no. 2, pp. 94-105, 2017.

[10] H. Heryadi, D. Darmawan, and $H$. Hernawan, "Pengaruh Multimedia Interaktif Berbasis Adobe Flash Untuk Meningkatkan Motivasi Dan Hasil Belajar Siswa Pada Mata Pelajaran Kewirausahan," JTEP-Jurnal Teknol. Dan Pembelajaran, vol. 2, no. 1, pp. 142-150, 2017. 
[11] D. T. P. Yanto, "Praktikalitas Media Pembelajaran Interaktif pada Proses Pembelajaran Rangkaian Listrik," INVOTEK J. Inov. Vokasional dan Teknol., vol. 19, no. 1, pp. 75-82, 2019, doi: 10.24036/invotek.v19i1.409.

[12] D. M. Ramli , M.Pd, "Media Teknlogi Pembelajaran," pp. 1-3, 2012.

[13] T. Nurrita, "Pengembangan Media Pembelajaran Untuk Meningkatkan Hasil Belajar Siswa," MISYKAT J. IImu-ilmu AlQuran, Hadist, Syari'ah dan Tarb., vol. 3, no. 1 , p. 171, 2018, doi: 10.33511/misykat.v3n1.171.

[14] G. De Donno and E. Cardarelli, "VEMl: A flexible interface for 3D tomographic inversion of time-and frequency-domain electrical data in EIDORS," Near Surf. Geophys., vol. 15, no. 1, pp. 43-58, 2017, doi: 10.3997/1873-0604.2016037.

[15] A. Sudianto and H. Ahmadi, "Rancang Bangun Sistem Informasi Penjualan Sparepart Motor Pada Bengkel Vinensi Motor Berbasis Web Guna Meningkatkan Penjualan dan Promosi Produk Pendahuluan Vinensi sepeda motor motor," Infotek J. Inform. dan Teknol., vol.

3, no. 2, pp. 32-39, 2020 